\title{
MAJOR CONSTRUCTIONAL DISPUTE CAUSES IN TURKEY
}

\author{
S.A. YILDIZEL ${ }^{1}$, E. DOGAN ${ }^{2}$, G. KAPLAN ${ }^{3}$, A. ERGUT ${ }^{4}$
}

\begin{abstract}
The possibility of construction disputes can be reduced, but they cannot be avoided due to the uncertain and risky nature of the building industry. Conflicts between construction parties often have very unfavourable effects, such as cost increases, poor construction quality and time extension in the schedule. Lots of studies have been carried out in order to try and avoid these disagreements. However, there are no common resolution tools or techniques due to the improving conditions and scope of contracted works. Advanced methods and dispute reasons should be fully monitored and updated for the applicable solutions. This paper discusses the current major constructional dispute reasons in Turkey. The questionnaire method was applied within the scope of this study. The questionnaire documents were randomly distributed to 80 contractors to analyse major dispute reasons in Turkey. Analysis of the questionnaire results indicates that the major current dispute causes are poor quality of performed works, delays in progress payments, inefficient site management, poorly written contracts and design mistakes.
\end{abstract}

Keywords: Constructional Disputes, Construction Industry in Turkey, The questionnaire method, Construction, Disagreement

\footnotetext{
${ }^{1}$ Res. Asst., PhD., Eng., Manisa Celal Bayar University, Faculty of Engineering, Muradiye Campus ,45140 Manisa, Turkey, e-mail: sadikalper.yildizel@cbu.edu.tr

${ }^{2}$ Asso. Prof., PhD., Eng., Manisa Celal Bayar University, Faculty of Engineering, Muradiye Campus ,45140 Manisa, Turkey, e-mail: erkan.dogan@cbu.edu.tr

${ }^{3}$ Lec., PhD., Eng., Kastamonu Vocational School, Kastamonu, Turkey, e-mail: gkaplan@kastamonu.edu.tr

${ }^{4}$ Asst. Prof., PhD., Eng., Manisa Celal Bayar University, Faculty of Engineering, Muradiye Campus ,45140 Manisa,

Turkey, e-mail: abdulkerim.ergut@cbu.edu.tr
} 


\section{INTRODUCTION}

The construction industry history began in the Paleolithic Age between 40,000 and 12,000 B.C., when human beings left their caves to adopt a domiciliary life [1]. There have been numerous disagreements between construction parties from then. Some research describes conflict as 'any pattern of stimulation presented to an organism which has the power to elicit two or more incompatible responses, the strengths of which are functionally equal [2]. Disputes are also unavoidable for the construction industry as compared to other disciplines due to the fact that building project managers deal with too many ambiguities [3]. The occurrence of an uncertainty boosts the possibility for a dispute within the scope of the construction project depending on the stressful conditions on a construction site. Not only general contractors experience this stress, but clients are also in a noticeably uncomfortable position. Some research states that, "disputes and conflicts are widespread as a result of severe problems with product quality and the highest rate of insolvency of any industry' [4]. A large amount of dispute sources are commonly contractual matters; including but not limited to changes in orders, problems with payments, technical document quality, management and strange client requirements. If a dispute is not properly monitored and solved, it can result in poor team morale and business development [5]. Beside its functional effects, disputes may have negative consequences on teams, workers and organizations [6]. Today's project management involves on-site dispute resolution processes to resolve immediate occurrences on a construction site [7]. Construction claims and disputes keep improving nowadays [8] and the situation does not differ in Turkey. On time completion of a project can be a good sign of efficiency. However, the construction industry in Turkey depends on many variables and factors from many sources. Unforeseen delays cause completion of projects within the planned timeframe to be a rarity.

Construction projects are one of the most problematic businesses in human life. Many diverse specialists are needed, and architects, quantity surveyors, designers, contractors, subcontractors and engineers must work together in order to complete the project within the scope of the expected budget. Apart from the technical skills and all related works, coordination of these people becomes considerable while dealing with complex projects [9].

A wide range of studies have been conducted to determine the major dispute causes in the construction industry. One of them was conducted by E Cakmak and P. Irlayici Cakmak in 2013, and dispute causes are classified as shown in Table 1[10]. 
The construction industry is the main locomotive of Turkey's domestic economy; however, it suffers from some problems between general contractors, subcontractors, owners and other parties. Any fluctuation in this sector creates big gaps in the national economy. In order to avoid monetary losses, the main causes shall be analysed and requested precautions should be taken into consideration. This study comprises the initial precaution stages.

Table 1. Common causes of disputes by category

\begin{tabular}{|c|c|}
\hline CATEGORY OF DISPUTES & CAUSES OF DISPUTES \\
\hline \multirow{6}{*}{ OWNER RELATED (A) } & Variations initiated by the owner \\
\hline & Change of scope \\
\hline & Late giving of possession \\
\hline & Acceleration \\
\hline & Unrealistic expectations \\
\hline & Payment Delays \\
\hline \multirow{6}{*}{ CONTRACTOR RELATED (B) } & Delays in work progress \\
\hline & Time extensions \\
\hline & Financial failure of the contractor \\
\hline & Technical inadequacy of the contractor \\
\hline & Tendering \\
\hline & Quality of works \\
\hline \multirow{3}{*}{ DESIGN RELATED } & Inadequate/ incomplete specifications \\
\hline & Quality of designs \\
\hline & Availability of information \\
\hline \multirow{4}{*}{ CONTRACT RELATED } & Ambiguities in contract documents \\
\hline & Different interpretations of the contract provisions \\
\hline & Risk allocation \\
\hline & Other contractual problems \\
\hline \multirow{3}{*}{ HUMAN BEHAVIOUR RELATED } & Adversarial / controversial culture \\
\hline & Lack of communication \\
\hline & Lack of team morale \\
\hline \multirow{2}{*}{ PROJECT RELATED } & Site conditions \\
\hline & Unforeseen changes \\
\hline \multirow{3}{*}{ EXTERNAL FACTORS } & Weather \\
\hline & Legal and economic factors \\
\hline & Fragmented structure of the sector \\
\hline
\end{tabular}




\section{Method AND DAta AnAlysis}

Published relevant studies were retrieved and 31 dispute causes were taken from that research. 80 construction companies and owners (Figure 1.1) were randomly selected and the questionnaire covers two parts: Part I is related to the general information of the company and Part II is related to conflict reason answers.

Table 2. Conflict causes in the Questionnaire form

\begin{tabular}{|c|c|}
\hline ITEM NO & CAUSE DESCRIPTION \\
\hline 1 & Fluctuation in Foreign Currency \\
\hline 2 & Design Mistakes \\
\hline 3 & Poorly Prepared Contracts \\
\hline 4 & Poor Application Projects \\
\hline 5 & Lack of Skilled Subcontractors \\
\hline 6 & Late Approval Time of Application Projects by the Owner \\
\hline 7 & Unskilled workers \\
\hline 8 & Severe Weather Conditions \\
\hline 9 & Poor site management by the Project Management Company (if applicable) \\
\hline 10 & Violation of Contract Clauses \\
\hline 11 & Poor Quality of Construction Materials \\
\hline 12 & Inaccurate Project Cost Estimation \\
\hline 13 & Late Evaluation of Completed Works \\
\hline 14 & Late decisions of Owner \\
\hline 15 & Severe Construction Site Conditions \\
\hline 16 & Fluctuation of Labor and Material Cost During Construction \\
\hline 17 & Poorly prepared Bill of Quantity Documents \\
\hline 18 & Inflation \\
\hline 19 & Financial problems of the Contractor \\
\hline 20 & Unforeseen problems \\
\hline 21 & Unproductive Labor \\
\hline 22 & Low Quality of Completed Works \\
\hline 23 & Scope Changes in the Project \\
\hline 24 & Unrealistic Contract Period \\
\hline 25 & Late payment by the owner \\
\hline 26 & Communication Errors \\
\hline 27 & Planning Mistakes \\
\hline 28 & Lack of national standards \\
\hline 29 & Delay from local authorities for any permissions \\
\hline 30 & Lack of equipment \\
\hline 31 & Low tender bids \\
\hline
\end{tabular}


These 31 conflict reasons (Table-2) are considered within the scope of this paper. 80 contractors, owners and subcontractors (Parties) are randomly selected and the questionnaire is applied to their areas of expertise in the civil engineering discipline. Participant backgrounds are presented in Figure 1. and Figure 2. Parties were requested to fill in the forms depending on their experience in the construction industry. Responses were ranked based on their severity index which are commonly preferred in this type of study $[11,12]$.

\section{Questionnaire Participants}

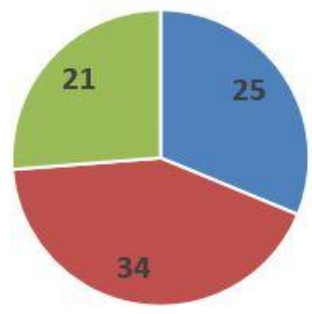

w Owner $=$ Contractor $=$ Subcontractor

Fig. 1. Questionnaire Participants

\section{Participant Construction Branches}

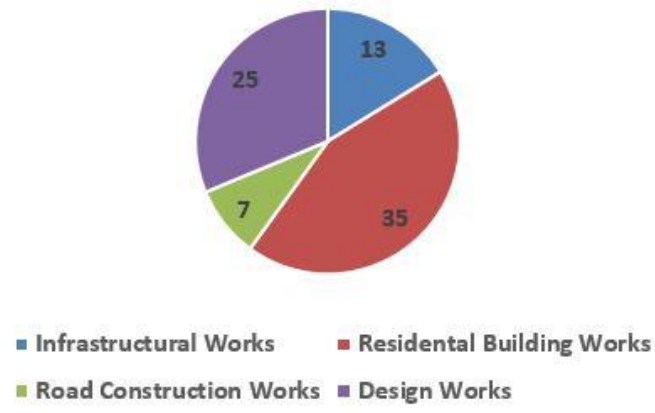

Fig. 2. Participant Construction Branches

The severity index is calculated with eq. (1) where $\mathrm{c}$ is the weighting response coefficient (ranges from 1 to $5 ; 1$ for very low, 5 for very high), $\mathrm{n}$ is for the frequency of the answers and $\mathrm{N}$ for total answers.

$$
\text { Severity Index }(\%)=\Sigma c(n / N) \times 100 / 5
$$


Table 3. Severity Index (S.I.) Analysis Results and Ranks

\begin{tabular}{|c|c|c|}
\hline CONFLICT CAUSES & S.I. $(\%)$ & RANK \\
\hline Low Quality of Completed Works & 77.0485 & 1 \\
\hline Late payment by the owner & 76.3436 & 2 \\
\hline Poor site management by the Project Management Company (if applicable) & 75.2863 & 3 \\
\hline Poorly Prepared Contracts & 65.0220 & 4 \\
\hline Design Mistakes & 64.9339 & 5 \\
\hline Unskilled workers (General Contractor) & 64.7577 & 6 \\
\hline Inflation & 62.4934 & 7 \\
\hline Fluctuation in Foreign Currency & 59.3172 & 8 \\
\hline Poor Application Projects & 58.1410 & 9 \\
\hline Lack of Skilled Subcontractors (Qualified Staff of Subcontractor) & 56.0529 & 10 \\
\hline Low tender bids & 54.7885 & 11 \\
\hline Inaccurate Project Cost Estimation & 52.7004 & 12 \\
\hline Late decisions of Owner & 50.5242 & 13 \\
\hline Unrealistic Contract Period & 49.4361 & 14 \\
\hline Severe Weather Conditions & 48.4359 & 15 \\
\hline Severe Construction Site Conditions & 47.2599 & 16 \\
\hline Late Approval Time of Application Projects by the Owner & 46.9958 & 17 \\
\hline Unproductive Labor & 44.9956 & 18 \\
\hline Scope Changes in the Project & 44.3789 & 19 \\
\hline Violation of Contract Clauses & 44.2907 & 20 \\
\hline Financial problems of the Contractor & 42.2026 & 21 \\
\hline Lack of national standards & 40.9383 & 22 \\
\hline Poor Quality of Construction Materials & 40.9381 & 23 \\
\hline Late Evaluation of Completed Works & 40.8502 & 24 \\
\hline Communication Errors & 38.6740 & 25 \\
\hline Lack of equipment & 38.4978 & 26 \\
\hline Fluctuation of Labor and Material Cost During Construction & 37.4099 & 27 \\
\hline Delay from local authorities for any permissions & 36.4096 & 28 \\
\hline Poorly prepared Bill of Quantity Documents & 35.4095 & 29 \\
\hline Unforeseen problems & 35.2338 & 30 \\
\hline Planning Mistakes & 34.2335 & 31 \\
\hline
\end{tabular}

In the following data analysis process, some statistical analysis techniques were applied to the questionnaire results such as weighted mean (W), coefficient of variation (CV) and standard deviation (S) in order to compare results with relevant studies (Table 4). 
Table 4. Statistical Analysis

\begin{tabular}{|c|c|c|c|}
\hline CONFLICT CAUSES & $\mathbf{W}$ & $\mathbf{S}$ & CV \\
\hline Low Quality of Completed Works & 4.27 & 0.08 & 2.14 \\
\hline Late payment by the owner & 4.21 & 0.39 & 10.01 \\
\hline Poor site management by the Project Management Company (if applicable) & 4.17 & 0.33 & 8.21 \\
\hline Poorly Prepared Contracts & 4.09 & 0.20 & 5.29 \\
\hline Design Mistakes & 4.03 & 0.25 & 6.59 \\
\hline Unskilled workers (General Contractor) & 3.94 & 0.38 & 10.34 \\
\hline Inflation & 3.84 & 0.49 & 12.21 \\
\hline Fluctuation in Foreign Currency & 3.75 & 0.32 & 8.74 \\
\hline Poor Application Projects & 3.63 & 0.39 & 10.94 \\
\hline Lack of Skilled Subcontractors (Qualified Staff of Subcontractor) & 3.59 & 0.44 & 12.58 \\
\hline Low tender bids & 3.54 & 0.56 & 15.84 \\
\hline Inaccurate Project Cost Estimation & 3.51 & 0.55 & 16.12 \\
\hline Late decisions of Owner & 3.44 & 0.41 & 16.34 \\
\hline Unrealistic Contract Period & 3.41 & 0.64 & 13.27 \\
\hline Severe Weather Conditions & 3.27 & 0.36 & 20.59 \\
\hline Severe Construction Site Conditions & 3.14 & 0.57 & 12.01 \\
\hline Late Approval Time of Application Projects by the Owner & 2.87 & 0.48 & 19.84 \\
\hline Unproductive Labor & 2.84 & 0.40 & 17.10 \\
\hline Scope Changes in the Project & 2.71 & 0.45 & 14.86 \\
\hline Violation of Contract Clauses & 2.64 & 0.27 & 16.24 \\
\hline Financial problems of the Contractor & 2.60 & 0.54 & 10.21 \\
\hline Lack of national standards & 2.54 & 0,42 & 20.84 \\
\hline Poor Quality of Construction Materials & 2.49 & 0.38 & 17.21 \\
\hline Late Evaluations of Completed Works & 2.41 & 0.51 & 14.34 \\
\hline Communication Errors & 2.39 & 0.47 & 19.94 \\
\hline Lack of equipment & 2.34 & 0.50 & 18.01 \\
\hline Fluctuation of Labor and Material Cost During Construction & 2.30 & 0.37 & 20.51 \\
\hline Delay from local authorities for any permissions & 2.27 & 0.52 & 17.01 \\
\hline Poorly prepared Bill of Quantity Documents & 2.24 & 0.46 & 22.14 \\
\hline Unforeseen problems & 2.19 & 0.34 & 18.21 \\
\hline Planning Mistakes & 2.14 & 0.42 & 13.54 \\
\hline
\end{tabular}

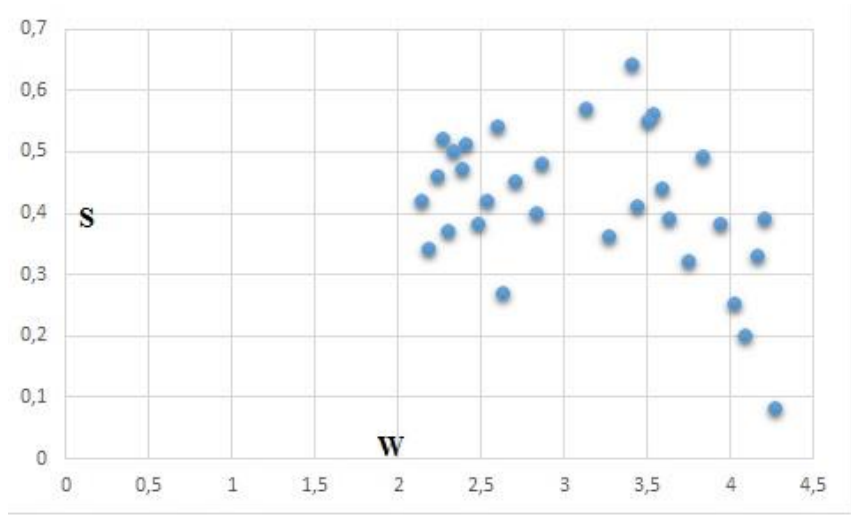

Fig. 3. Cause mean versus standard deviation 


\section{RESULTS AND DISCUSSION}

Study results show that the main five dispute causes are Low Quality of Completed Works, Late payment by the owner, Poor site management by the Project Management Company, Poorly Prepared Contracts, and Design mistakes.

- Low Quality of Completed Works: This dispute type is commonly faced in the construction industry in Turkey. As per the information obtained from interviewer, it can be caused by poor and unskilled labor and unsuccessful quality control and assurance systems. Subcontractors' and contractors' monthly progress amount can be deducted by the owner even if they have met all relevant standard requirements. New working systems should be improved and embedded in the construction industry for all work periods, including the bidding processes.

- Late Payment by the Owner: Contractors and subcontractors complain about late payments from the owner and their ability to contract cash flow dates. They indicate that owners gain some benefit from the interest of delayed payments. In order to lower the risk of the occurrence of this type of conflict, payment agreement clauses should be more detailed and the owners' actions should be limited in legal ways to resolve the grievances of the contractors and subcontractors.

- Poor site management by the Project Management Company: Accredited and professional project management companies should be hired by the owner regardless of the cost. Unproductive planning and scheduling of construction works may lead to high cost overruns comparing to the project management hiring expenses.

- Poorly Prepared Contracts: All works and actions are guided by the main contracts. Any error and or lack of any clauses result in great money losses. Interviewers indicate that there is no common and effective agreement form in Turkey. Their thoughts emphasize the need for fair of agreement content. In order to eliminate these problems, contract preparation stages should be in compliance with European contracting and bidding standards. The language of the agreement should be clear and unambiguous. More contract detail control systems can be improved and used from the tender process to the project completion date.

- Design Mistakes: Design mistakes have always had negative effects on the project's success. Design changes which are caused by design mistakes also result in disputes among the parties concerning project completion date, project costs and so on. Therefore, the owner 
should hire professional design services and the parties should conduct, jointly, and more detailed, site investigations in order to avoid any unforeseen dispute resources.

Table 4 covers the calculations of weighted mean, variation coefficient and standard deviation. Table 4 values reflect reasonable data as maximum standard deviation is 0.64 and the maximum coefficient of variation is $22.14 \%$. As per the results of Figure 3., good and consistent data has been obtained between the severity indexes and dispute causes. All analyses results are generally in line with the relevant research.

Besides the above mentioned top 5 dispute causes, other factors should be identified and studied in detail in order to prevent all types of losses on construction sites in Turkey. As a member of the world's top 20 growing economies, adequate precautions should be taken to ensure the development of the economy.

\section{REFERENCES}

1. Zhou, Z., Goh, Y. M., \& Li, Q. (2015). Overview and analysis of safety management studies in the construction industry. Safety Science. doi:10.1016/j.ssci.2014.10.006.

2. Maher, B.A., (1964). The Application of the Approach-Avoidance Conflict Model to Social Behavior. The Journal of Conflict Resolution, Vol. 8, No. 3 (Sep., 1964), pp. 287-291.

3. Whitfield, J. (1994). Conflicts in construction, avoiding, managing and resolving. London: Macmillan Press.

4. Clegg, SR (1992) Contracts cause conflicts. In P Fenn \& R Gameson (eds) Construction Conflict Management and Resolution. Proceedings of the First International Construction Management Conference, Spon, London.

5. Cheung, S. O., \& Suen, C. H. (2002). A multi-attribute utility model for disputes resolution strategy selection Construction Management Economy, 20, 557-568

6. Pondy, L. R. (1967). Organizational conflict. Administrative Science Quarterly, 12(2), 296-320.

7. Shin, K.-C. K. (2000). Identification of critical disputes characteristic (cdes) during construction project operations. Georgia Institute of Technology, Georgia.

8. Arditi, D., \& Pulket, T. (2005). Predicting the outcome of construction litigation using boosted decision trees. Journal of Computing In Civil Engineering (C) ASCE, 387-393.

9. Naaranoja, M., \& Uden, L. (2007). Major problems in renovation projects in Finland. Building and Environment, 42(2), 852-859. http://doi.org/10.1016/j.buildenv.2005.10.001.

10. Cakmak E., Cakmak P.I. (2014). An analysis of causes of disputes in the construction industry using analytical network process. Procedia - Social and Behavioral Sciences 109,183 - 187.

11. Assaf, S. A., \& Al-Hejji, S. (2006). Causes of delay in large construction projects. International Journal of Project Management, 24(4), 349-357. http://doi.org/10.1016/j.ijproman.2005.11.010.

12. Mahamid, I. (2014). Micro and macro level of dispute causes in residential building projects: Studies of Saudi Arabia. Journal of King Saud University - Engineering Sciences. http://doi.org/10.1016/j.jksues.2014.03.002. 


\section{LIST OF FIGURES AND TABLES:}

Fig. 1. Questionnaire Participants

Rys. 1. Uczestnicy ankiety

Fig. 2. Participant Construction Branches

Rys. 2. Branże budownictwa uczestników

Fig. 3. Cause mean versus standard deviation

Rys. 3. Element przyczynowy a odchylenie standardowe

Tab. 1. Common causes of disputes by category

Tabela 1. Najczęstsze przyczyny sporów według kategorii

Tab. 2. Conflict causes in the Questionnaire form

Tabela 2. Przyczyny konfliktów w formularzu ankiety

Tab. 3. Severity Index (S.I.) Analysis Results and Ranks

Tabela 3. Wyniki i rangi analizy wskaźnika dotkliwości (Severity Index, SI)

Tab. 4. Statistical Analysis

Tabela 4. Analiza statystyczna 


\section{GLÓWNE POWODY SPORÓW BUDOWLANYCH W TURCJI}

Slowa kluczowe: spory budowlane, budownictwo w Turcji, ankietyzacja, budownictwo, konflikty

\section{STRESZCZENIE:}

Prawdopodobieństwo sporów budowlanych może zostać obniżone, jednakże nie można ich uniknąć, ze względu na niepewną i ryzykowną naturę przemysłu budowlanego. Konflikty pomiędzy stronami inwestycji często mają bardzo niekorzystny wpływ, taki jak wzrost kosztów, słaba jakość konstrukcji oraz wydłużenia czasowe w harmonogramie. W celu uniknięcia tych nieporozumień, przeprowadzono wiele badań. Jednakże, nie ma wspólnych narzędzi lub technik rozwiązywania tych problemów, ze względu na poprawiające się warunki oraz zakres prac budowlanych. Metody zaawansowane oraz powody sporów powinny być w pełni monitorowane i aktualizowane pod kątem stosownych rozwiązań. Niniejsza praca omawia obecne, główne powody sporów budowlanych w Turcji. W zakresie niniejszej pracy zastosowano metodę ankietowania. Ankiety zostały losowo rozdane 80 wykonawcom w celu przeanalizowania głównych przyczyn sporów w Turcji. Analiza wyników ankiety wskazuje, że obecnie głównymi powodami sporów są słaba jakość wykonanych prac, opóźnienia w płatności transz, nieefektywne zarządzanie budową, źle sformułowane umowy oraz błędy projektowe. Historia przemysłu budowlanego ma swój początek w Paleolicie, pomiędzy 40000 a 12000 p.n.e., kiedy to istoty ludzkie opuściły swoje jaskinie, aby przystosować się do życia domowego. Od tego momentu miała miejsce niezliczona ilość nieporozumień pomiędzy stronami inwestycji. Niektórzy badacze określają konflikt jako 'jakąkolwiek formę stymulacji organizmu, która ma moc wywołania dwóch lub więcej sprzecznych odpowiedzi, których mocne strony są funkcjonalnie równe. w przemyśle budowlanym, w porównaniu do innych branż, spory są nieuniknione również ze względu na fakt, że kierownicy projektów mają do czynienia ze zbyt duża liczbą niejasności. Pojawienie się niejasności zwiększa szansę sporu w zakresie projektu budowlanego, w zależności od warunków stresujących na placu budowy. Nie tylko główni wykonawcy doświadczają tego stresu, ale i klienci są w zauważalnie niekomfortowej pozycji. Niektóre badania stwierdzają, że spory i konflikty są tak powszechne ze względu na poważne problemy z jakością produktu oraz najwyższy wskaźnik niewypłacalności ze wszystkich przemysłów. Dużą liczbą źródeł sporów są powszechne sprawy kontraktowe: w tym, między innymi, zmiany zamówień, problemy z płatnościami, jakość dokumentacji technicznej, zarządzanie oraz dziwne wymagania klienta. Spór może skutkować słabymi morale zespołu oraz rozwojem biznesu jeśli nie jest odpowiednio monitorowany oraz rozwiązany. Poza wpływami funkcjonalnymi, spory mogą mieć negatywne konsekwencje również w odniesieniu do zespołów, pracowników oraz organizacji. Zarządzanie projektem w dzisiejszym czasach obejmuje procesy rozwiązywania sporów na miejscu, aby natychmiast rozstrzygać problemy pojawiające się na budowie. Kwestia roszczeń i sporów obecnie się poprawia, a sytuacja w Turcji nie jest inna. Terminowe zakończenie projektu może być dobrym wyznacznikiem efektywności. Jednakże przemysł budowlany w Turcji zależy od wielu zmiennych i czynników, z wielu źródeł. Nieprzewidziane opóźnienia powodują, że kończenie inwestycji w zaplanowanych ramach czasowych jest rzadkością. Projekty budowlane są jednymi z najbardziej problematycznych przedsięwziąć w życiu ludzkim. Potrzebnych jest wielu przeróżnych specjalistów, a architekci, geodeci, projektanci, wykonawcy, podwykonawcy, a także inżynierowie, muszą razem współpracować, aby zakończyć projekt w zakresie zaplanowanego budżetu. Poza umiejętnościami technicznymi oraz wszystkimi powiązanymi pracami, koordynacja tych osób staje się poważnym zadaniem w przypadku złożonych projektów. Szeroki wachlarz badań został przeprowadzony w celu ustalenia głównych przyczyn sporów w przemyśle budowlanym. Jedno $\mathrm{z}$ nich zostało przeprowadzone przez E. Cakmak i P. Irlayici Cakmak w 2013, a przyczyny sporów zostały sklasyfikowane. Przemysł budowlany jest 
głównym motorem napędowym krajowej gospodarki Turcji; jednakże, cierpi z powodu niektórych problemów pomiędzy głównymi wykonawcami, podwykonawcami, klientami oraz innymi stronami. Jakiekolwiek wahania w tym sektorze powodują wielkie wyrwy w gospodarce kraju. W celu uniknięcia strat pieniężnych należy zanalizować główne przyczyny, a wymagane środki zapobiegawcze należy wziąć pod uwagę. Niniejsza praca obejmuje wstępne etapy prewencyjne. Odzyskano opublikowane, stosowne badania, a 31 przyczyn sporów zostało zaczerpniętych z tych prac. Losowo wybrano 80 firm budowlanych oraz klientów, a kwestionariusz obejmuje dwie części: Część I odnosi się do ogólnych informacji o firmie, a Część II do odpowiedzi dotyczących przyczyn konfliktów. Te 31 przyczyn konfliktów jest wziętych pod uwagę w zakresie niniejszej pracy. 80 wykonawców, klientów oraz podwykonawców (Stron) zostało losowo wybranych, a kwestionariusz został dostosowany do ich obszarów działalności z branży budownictwa lądowego. Strony zostały poproszone o wypełnienie formularzy, w zależności od ich doświadczenia w przemyśle budowlanym. Odpowiedzi zostały sklasyfikowane w oparciu o ich wskaźnik dotkliwości, co jest powszechnie stosowane w tego typu badaniach.

- Niska Jakość Zakończonych Prac: Ten typ sporu jest powszechnie spotykany w tureckim przemyśle budowlanym. Zgodnie $\mathrm{z}$ informacjami uzyskanymi od ankietowanych, może być spowodowana słabą i niewykwalifikowaną siłą roboczą oraz nieskutecznymi systemami kontroli i zapewnienia jakości. Miesięczny postęp podwykonawców i wykonawców może być przez klienta zmniejszony, nawet jeśli dopełnili wszystkich stosownych wymagań standardowych. Należy poprawić i wprowadzić nowe systemy pracy w przemyśle budowlanym, na wszystkie okresy pracy, w tym na procesy przetargowe.

- Opóźniona Platność Klientów: Wykonawcy i podwykonawcy narzekają na opóźnione płatności od klienta oraz jego możliwość umownego ustalania dat przepływu pieniędzy. Wskazują oni, że klienci uzyskują pewne korzyści z oprocentowania na opóźnionych płatnościach. W celu obniżenia ryzyka wystąpienia takiego typu konfliktu, klauzule umowne dotyczące płatności powinny być bardziej szczegółowe, a działania klientów powinny być prawnie ograniczone, aby rozwiązywać skargi wykonawców i podwykonawców.

- Slabe zarządzanie budową przez Firmę Zarządzającą Projektem: Akredytowane i profesjonalne firmy zarządzające projektami powinny być zatrudniane przez klienta niezależnie od kosztów. Bezproduktywne planowanie i harmonogramowanie robót budowlanych może prowadzić do znaczących przekroczeń kosztów, w porównaniu z kosztami najmu firm zarządzających projektem.

- Slabo Przygotowane Umowy: Wszystkie prace i działania są kierowane przez umowy główne. Jakiekolwiek błędy lub brak jakichkolwiek klauzul, skutkują wielkimi stratami pieniężnymi. Ankietowani wskazywali, że w Turcji nie istnieje jedna i efektywna forma porozumienia. W swoich opiniach podkreślali potrzebę sprawiedliwej treści umowy. W celu wyeliminowania tych problemów, etapy przygotowania umowy powinny być zgodne z europejskimi normami podpisywania umów i przetargów. Język umowy powinien być jasny i jednoznaczny. Jeszcze bardziej można poprawić i wykorzystywać szczegółowe systemy kontroli umów, od procedur przetargowych do daty zakończenia projektu.

- Błędy Projektowe: Błędy projektowe od zawsze negatywnie wpływały na sukces projektu. Zmiany w projekcie, spowodowane błędami projektowymi, również skutkują sporami pomiędzy stronami, odnośnie daty zakończenia projektu, kosztów projektu itd. Dlatego też, klient powinien zatrudnić profesjonalne służby projektowe, a strony powinny wspólnie i bardziej szczegółowo przeprowadzać wizje lokalne w celu uniknięcia jakichkolwiek, nieprzewidzianych, powodów sporu. 